\title{
Effects of leaf position, surface, and entry sites on Quambalaria eucalypti infection in eucalypt
}

\author{
Reginaldo G. Mafia ${ }^{1}$, Acelino C. Alfenas ${ }^{2}$, Eraclides M. Ferreira ${ }^{2}$, Gabriela C.G. Andrade ${ }^{3}$, Cláudia A. \\ Vanetti $^{4}$ \& Daniel H.B. Binoti ${ }^{2}$
}

${ }^{1}$ Aracruz Celulose S.A, Centro de Pesquisa e Tecnologia, Aracuz, ES, Brazil; ${ }^{2}$ Departamento de Fitopatologia, Universidade Federal de Viçosa, 36570-000, Viçosa, MG, Brazil; ${ }^{3}$ Monsanto do Brasil, Morrinhos, GO, Brazil; ${ }^{4}$ Núcleo de Microscopia e Microanálise, Universidade Federal de Viçosa, 36570-000, Viçosa, MG, Brazil

Author for correspondence: Acelino C.Alfenas, e-mail: aalfenas@ufv.br

\begin{abstract}
The objectives of this study were to determine the effects of leaf position, surface, and the need for entry sites, such as wounds, other pathogen lesions or natural openings, to promote infection of Quambalaria eucalypti in Eucalyptus spp. We carried out a series of artificial inoculations in wounded and unwounded leaves from seedlings of Eucalyptus globulus and two hybrid clones (UFV-100 - E. grandis $\mathrm{x}$ E. urophylla and UFV-101 - E. saligna x E. maidenii). E. globulus was more susceptible to infection than clones UFV-100 and UFV-101. Artificial wounds greatly favored pathogen penetration. However, old lesions caused by Cylindrocladium pteridis and Puccinia psidii did not provide infection sites for Q. eucalypti. Differences in fungal spore germination and leaf surface colonization were not observed between expanding and fully expanded leaves. Q. eucalypti penetrated through the wounded leaves and we didn't observe direct penetration thought the epidermis. Stomata neither attracted nor repelled germ tube and somatic hyphae. Young expanding leaves were more susceptible to Q. eucalypti infection than fully expanded leaves located in the upper third of the plant. Infection took place preferentially on the abaxial leaf surface.
\end{abstract}

Keywords: Eucalyptus, host-pathogen interaction, inoculation protocol, leaf spot.

\section{RESUMO}

Efeito da posição e superfície foliar sobre a infecção de Quambalaria eucalypti e determinação sítios de entrada em eucalipto

Objetivou-se, neste estudo, determinar os efeitos da posição da folha, superfície foliar e os sítios de entrada, assim como ferimentos, lesões de outros patógenos ou aberturas naturais sobre a infecção de Quambalaria eucalypti em Eucalyptus spp. Para isso, realizaram-se inoculações artificiais em folhas de mudas seminais de Eucalyptus globulus e dois clones híbridos de Eucalyptus (UFV-100 - E. grandis x E. urophylla e UFV-101 - E. saligna x E. maidenii). E. globulus foi mais suscetível à infecção que os clones UFV-100 e UFV-101. Os ferimentos artificiais favoreceram a penetração do patógeno. Entretanto, lesões velhas causadas por Cylindrocladium pteridis e Puccinia psidii não foram sítios de entrada de Q. eucalypti. Não foram observadas diferenças na germinação de esporos e colonização entre folhas em expansão e completamente expandidas. Q. eucalypti penetrou em folhas com ferimentos. Contudo não foi possível observar a penetração direta através da epiderme. Folhas jovens foram mais suscetíveis à infecção de $Q$. eucalypti que folhas completamente expandidas no terço superior da planta. A infecção ocorreu preferencialmente na superfície abaxial da folha.

Palavras-chave: Eucalyptus, interação patógeno-hospedeiro, protocolo de inoculação, mancha foliar.

\section{INTRODUCTION}

Quambalaria leaf and shoot blight of Corymbia and Eucalyptus spp. is caused by three species of Quambalaria (Simpson, 2000; Roux et al., 2006). These are Q. eucalypti (M.J. Wingf., Crous \& W.J. Swart) J.A. Simpson, $Q$. pitereka (J. Walker \& Bertus) J.A. Simpson and Q. pusilla (U. Braun \& Crous) J.A. Simpson. Q. pitereka is known only from Australia, where it is an economically important pathogen in eastern Australia (Simpson, 2000). Q. eucalypti occurs in Brazil (Alfenas et al., 2004; Zauza et al., 2003) and South Africa (Wingfield et al., 1993), while Q. pusilla has been reported only from Thailand (Simpson, 2000).
Stem girdling and leaf spot, caused by $Q$. eucalypti, has arisen as one of the most important eucalypt diseases in nurseries in Brazil. The disease is characterized by a white mass of mycelium and other fungal structures covering the brownish lesions, concentrated mainly on the abaxial surface, and resembling pustules of white rust. This pathogen was reported to cause similar symptoms in minicuttings and seedlings of $E$. urophylla $\mathrm{x}$ E. maidenii, E. globulus and their hybrids. It has now spread throughout the main Brazilian eucalypt producing regions, reaching the states of Amapá, Bahia, Espírito Santo, Minas Gerais, Rio Grande do Sul, and São Paulo. One year after the first record in Brazil, this pathogen was also reported in Cerro Colorado, Uruguay, causing the same disease in 
E. globulus grown in greenhouses as well as leaf spot and canker in the field (Alfenas et al., 2004).

Although $Q$. eucalypti is among the most important pathogens associated with clonal propagation of eucalyptus, little is known about the host-pathogen interaction, including the mode of penetration and the influence of leaf phenological age and which leaf surface is more susceptible to infection. Therefore, the aim of this study was to determine how and where the pathogen penetrates the host leaves and how leaf phenological age affects infection.

\section{MATERIALS AND METHODS}

\section{Isolation and inoculum preparation}

Isolation was performed from eucalyptus leaves showing typical disease symptoms, collected from clonal mini-hedges. Spores were transferred from the lesions to Petri dishes containing potato dextrose agar (PDA) medium and incubated at $27^{\circ} \mathrm{C}$ in the dark. After $48 \mathrm{~h}$ the growing colonies were transferred to tubes containing PDA and kept at $5^{\circ} \mathrm{C}$ until used. Inoculations were performed with isolate S25, previously characterized morphologically as belonging to the species $Q$. eucalypti and proven to be pathogenic to eucalyptus. Small portions of the culture containing mycelia and spores were placed on the surface of PDA medium in Petri dishes and incubated at $27^{\circ} \mathrm{C}$ in the dark. After $72 \mathrm{~h}$ incubation a spore suspension at $2 \times 10^{5}$ conidia $/ \mathrm{mL}$ was prepared for inoculation.

\section{Plant material}

Cuttings of two hybrid clones, UFV-100 (E. grandis x E. urophylla) and UFV-101 (E. saligna x E. maidenii) and seedlings of E. globulus, grown for 30 days in $2 \mathrm{~L}$ pots containing potting medium, were used for inoculations. The plants were fertilized weekly as previously described (Alfenas et al., 2004).

\section{Preferential sites of penetration}

To determine the fungus sites of penetration, leaf segments of $1 \mathrm{~cm}^{2}$ of three seedlings E. globulus were inoculated separately on the adaxial and abaxial surfaces of pairs of leaves located on the upper and lower thirds of the plant by depositing a $20 \mu \mathrm{L}$ drop of spore suspension $\left(2 \times 10^{5}\right.$ conidia $/ \mathrm{mL}$ ). Leaf fragments were collected and examined 24 and $48 \mathrm{~h}$ after inoculation using a scanning electron microscope (SEM). The tissue fragments were transferred to vials containing glutaraldehyde solution $(3 \%)$ in $0.05 \mathrm{M}$ sodium cacodylate buffer ( $\mathrm{pH}$ 6.9). The vials were sealed, stored at $4^{\circ} \mathrm{C}$ for $12 \mathrm{~h}$ and the material was then submitted to six successive $10 \mathrm{~min}$ washes using the same buffer. After this prefixation the plant material was fixed in $1 \%$ osmium tetroxide solution $\left(\mathrm{OsO}_{4}\right)$ in cacodylate buffer and stored at $4^{\circ} \mathrm{C}$ for $4 \mathrm{~h}$. The material was then submitted to a new series of six washes as described above (Souza, 1998). After fixation, the material was dehydrated in an alcohol series of 30, 50, 70, 80 and 95\% for $10 \mathrm{~min}$ each, and then kept in 100\% ethanol for $15 \mathrm{~min}$. The material was dried to the critical point using liquid $\mathrm{CO}_{2}$ (Balzers, model CDP-030). The dried fragments were fixed on metallic supports and pulverized with gold (Balzers, model SCA 010). Finally, the fragments were observed in an SEM (LEO, model $1430 \mathrm{VP}$ ) at voltage accelerations of 15 and 20 $\mathrm{kV}$ and working distances of 17,18 and $19 \mathrm{~mm}$.

In two other experiments, we evaluated the influence of wounds and lesions of other pathogens on $Q$. eucalypti infection. In the first, wounds were artificially made by rubbing 600-mesh Carborundum over the leaf surfaces. The plants were spray inoculated $\left(2 \times 10^{5}\right.$ conidia $\left./ \mathrm{mL}\right)$ and subsequently maintained in a growth chamber $\left(28 \pm 2^{\circ} \mathrm{C}, 80 \pm 5 \%\right.$ humidity and $36 \mu \mathrm{mol} \cdot \mathrm{s}^{-1} \mathrm{~m}^{-2}$ light intensity, $12 \mathrm{~h}$ photoperiod). Injury free, inoculated and uninoculated plants were included as control. In the second experiment, cuttings of clone UFV100 showing lesions typical of Cylindrocladium pteridis and Puccinia psidii were sprayed with an inoculum suspension of $2 \times 10^{5}$ conidia $/ \mathrm{mL}$ and incubated in the growth chamber as previusly described. Asymptomatic inoculated plants and uninoculated plants were included as controls. Five eucalypt plants were used per treatment and three pairs of leaves on each plant were inoculated. All treatments were evaluated at $24 \mathrm{~h}$ intervals.

\section{Infection frequency as a function of phenological age and leaf surface}

Infection frequency of $Q$. eucalypti was evaluated according to the age and surface of the leaf in cuttings of eucalyptus clones UFV-100 and UFV-101. Three pairs of leaves representing three phenological ages were chosen: expanding leaves (upper third), expanded leaves (middle third) and senescing leaves (lower third). Artificial wounds were made on leaf surfaces (abaxial, adaxial or both) and atomizer inoculated, as described previously. The plants were kept in the growth chamber under the conditions already described. Five plants of each clone were used and the leaves were examined daily for disease symptoms.

\section{Influence of leaf phenological age on spore production}

Eucalypt clone UFV 100 was inoculated by inoculum deposition in order to evaluate the influence of phenological age on inoculum production. Three leaves from each third of the plant were used and wounds were artificially made using a device formed by 50 needles $(7 \mathrm{~mm} \varnothing)$ grouped together. Mycelial disks $(8 \mathrm{~mm})$ were collected from the borders of actively growing $(72 \mathrm{~h})$ Q. eucalypti cultures and placed on the wounds. The plants were transferred to a mist chamber at $25^{\circ} \mathrm{C}$. After $12 \mathrm{~h}$, the plants were transferred to a growth chamber $\left(28 \pm 2^{\circ} \mathrm{C}, 80 \pm 5 \%\right.$ humidity and $36 \mu \mathrm{mol} \mathrm{s}^{-1} \cdot \mathrm{m}^{-2}$ light intensity, $12 \mathrm{~h}$ photoperiod). Six days after inoculation, three leaf disks $(9 \mathrm{~mm})$ were cut and placed in test tubes containing $10 \mathrm{~mL}$ distilled water and $10 \mu \mathrm{L}$ Tween 20 and agitated for $1 \mathrm{~min}$ at $2200 \mathrm{rpm}$. The number of conidia $/ \mathrm{mL}$ in the suspension was determined and converted to conidia/ $\mathrm{cm}$ leaf area. 


\section{Statistical procedures}

Analysis of variance (ANOVA) and Fisher's protected LSD test were conducted using SAS statistical software (SAS Institute, Cary, NC). All experiments were replaced two times to confirm the obtained results.

\section{RESULTS}

\section{Preferential sites of penetration}

The observation of $Q$. eucalypti infected tissues by SEM showed that macroconidia (Figure 1A) and microconidia germinated on leaf surfaces $24 \mathrm{~h}$ after inoculation, and presented right angle branching (Figure
1B) with a great number of secondary and tertiary (thinner) branches at both evaluation times. Fungi colonization was higher on abaxial than adaxial leaf surface (Figure 1C-D). Hyphal anastomoses were also very frequent. A smaller number of spores germinated and remained adhered to the adaxial surface and these presented short, rarely branched germ tubes. No differences between fungal spore germination and colonization of leaf surface in expanding and expanded leaves were observed (data not shown).

Adhesion of the fungus on the epidermal surface occurred mainly along germ and somatic hyphae, especially when hyphal growth occurred in the cavity formed at the junction of two epidermal cells. Germ tube and primary
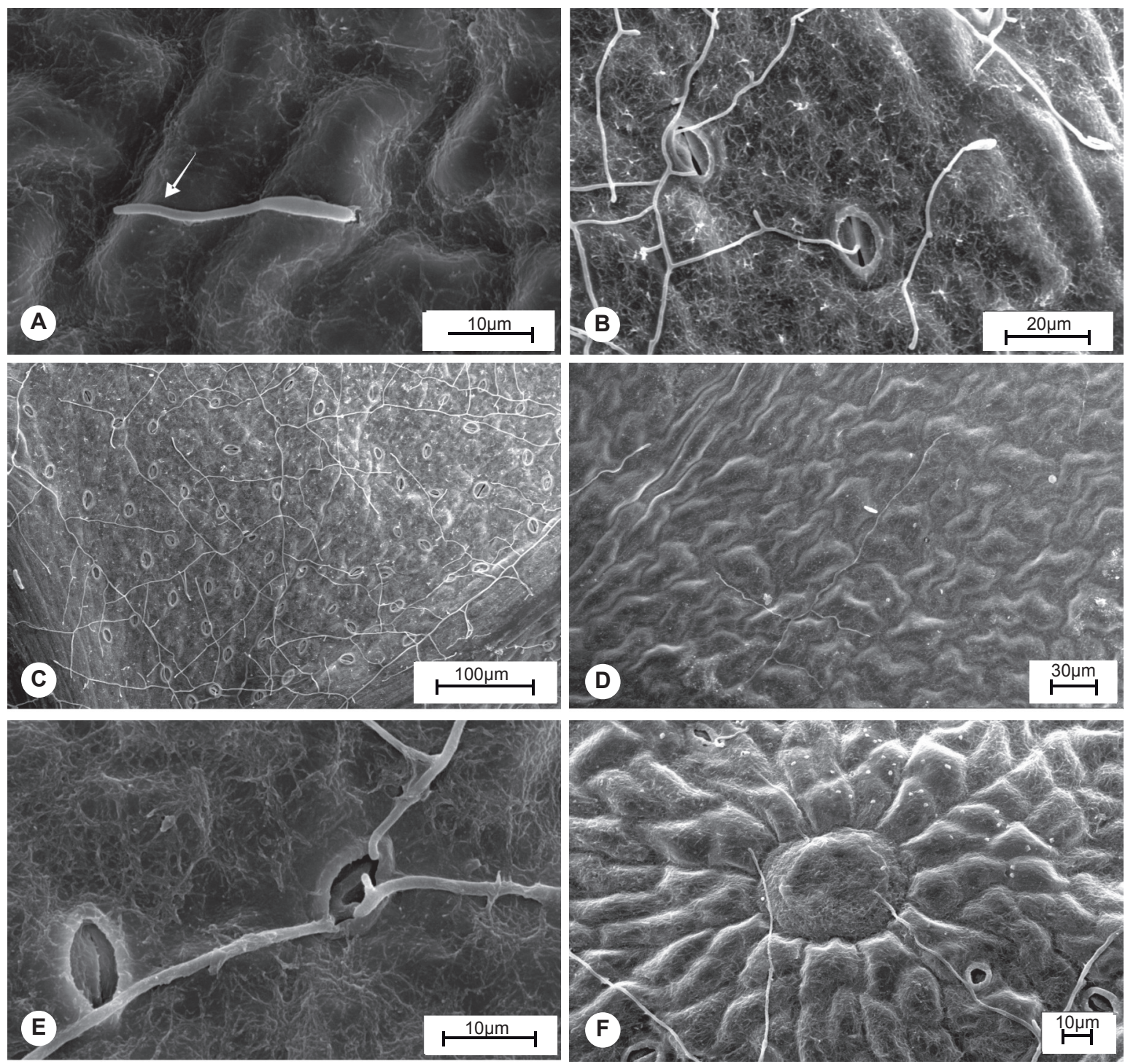

FIGURE 1 - Scanning electron microscope of eucalypt leaf tissue infected by Quambalaria eucalypti: A. Germ tube (arrow); B. Hyphal development without apressorium formation; C and D. Germination and colonization of the abaxial (C) and adaxial (D) surfaces from the lower third; E. Visual evidence of lack of attractive effect of stomata; F. Evidence that oil grand did not affect hyphal growth. 
hypha grew straight without specific direction. Hyphae were not attracted or repelled by the stoma and grew around or into the structure (Figure 1E). Direct hyphal penetration and through stomata were not observed. As occurred with the stomata, the oil glands did not exert any attractive or repulsive effect on hyphal growth (Figure 1F).

E. globulus was more susceptible to infection by Q. eucalypti than clone UFV-100 (moderately susceptible) or clone UFV-101 (moderately resistant). The artificial wounds greatly favored pathogen penetration and a shorter average latent period (ALP) was observed after wounding. The reduction in ALP varied according to the genetic material, decreasing by up to 3 days for artificially wounded clone UFV-100 and by up to 2 days for clone UFV- 101 . Unwounded clone UFV-101 plants did not show typical lesions 18 days after inoculation (Table 1). These results indicate that the relative importance of the presence of foliar wounds on resistance differs among eucalypt genetic material. The inoculation of seedlings presenting leaf lesions caused by C. pteridis and P. psidii with Q. eucalypti did not result in infection, confirming that old lesions are not used as infection sites.

\section{Infection frequency as a function of phenological age and leaf surface}

Infection occurred on both surfaces of leaves of all phenological ages. A greater infection frequency was observed in expanding leaves (upper third) than in expanded (middle third) and old leaves (lower third), especially for clone UFV-101, characterized as more resistant than clone UFV-100. Infection frequency varied from $66.6 \%$ and $25.9 \%$ (lower third) to $98.1 \%$ and $75.9 \%$ (upper third), for clones UFV-100 and UFV-101, respectively (Table 2). For clone UFV-100, the artificial inoculations made on the abaxial or both leaf surfaces were more effective (Figure 2A and Figure 2B) than those made only on adaxial surfaces, producing $27.8 \%$ (abaxial) and $25.0 \%$ (both surfaces) increases in infection frequency. For the moderately resistant clone UFV-101, the inoculation on both leaf surfaces promoted the greatest infection frequency while the inoculation on the abaxial surface presented intermediate values. Infection frequency caused by inoculation in both leaf surfaces

TABLE 1 - Mean latent period of Quambalaria eucalypti inoculated on unwounded and artificially wounded leaves of Eucalyptus spp.

\begin{tabular}{lccc}
\hline \hline \multirow{2}{*}{$\begin{array}{l}\text { Genetic } \\
\text { material }\end{array}$} & $\begin{array}{c}\text { Average latent period } \\
\text { (days) }\end{array}$ & $\begin{array}{c}\text { Level of } \\
\text { resistance }^{\mathbf{z}}\end{array}$ \\
\cline { 2 - 4 } & Wounded & Unwounded & \\
\hline Clone UFV-100 & 06 & 09 & $\mathrm{MS}$ \\
Clone UFV-101 & 12 & $>18$ & $\mathrm{MR}$ \\
Eucalyptus globulus & 03 & 05 & $\mathrm{~S}$ \\
\hline
\end{tabular}

\footnotetext{
z Susceptible (S), moderately susceptible (MS) and moderately
} resistant (MR).
TABLE 2 - Quambalaria eucalypti infection frequency as a function of leaves position (upper, middle and lower thirds) and as a function of leaf surface of clones UFV-100 (susceptible) and UFV-101 (resistant). Spore production as a function of leaf position of clone UFV 100

\begin{tabular}{cccc}
\hline \hline Genetic material & \multicolumn{3}{c}{ Leaf position } \\
& Upper & Middle & Lower \\
\hline UFV 100 & $98.14 \mathrm{a}^{\mathrm{z}}$ & $70.35 \mathrm{~b}$ & $66.63 \mathrm{~b}$ \\
UFV 101 & $75.91 \mathrm{a}$ & $51.82 \mathrm{~b}$ & $25.91 \mathrm{c}$ \\
\hline & \multicolumn{3}{c}{ Leaf surface } \\
\hline & Abaxial & Adaxial & Abaxial + adaxial \\
UFV 100 & $85.16 \mathrm{a}$ & $66.64 \mathrm{~b}$ & $83.32 \mathrm{a}$ \\
UFV 101 & $55.53 \mathrm{~b}$ & $25.91 \mathrm{c}$ & $72.2 \mathrm{a}$ \\
\hline & \multicolumn{3}{c}{ Sporulation (conidia $\mathbf{1 0} \mathbf{1 0}^{\mathbf{5}} \mathbf{m m}^{-2}$ ) } \\
\hline & Upper & Middle & Lower \\
UFV 100 & $3.55 \mathrm{a}$ & $2.35 \mathrm{a}$ & $0.69 \mathrm{~b}$ \\
\hline
\end{tabular}

${ }^{\mathrm{z}}$ Means followed by the same letter in a line do not differ significantly (Fisher's protected LSD test, $\mathrm{P}<0.05$ ).

increased $30 \%$ over that caused by inoculation made only on the abaxial surface and $178.7 \%$ over that caused by inoculation only on the adaxial surface (Table 2).

\section{Influence of leaf phenological age on spore production}

Secondary inoculum production was significantly higher in expanding and expanded leaves than in leaves in final vegetative stages (Figure 2C, Figure 2D and Figure 2E). Sporulation on leaves from the upper third was on average 4 times greater than on those from lower third (Table 2).

\section{DISCUSSION}

In the $Q$. eucalypti-eucalypt pathosystem the pathogen preferentially penetrated through artificial wounds, in agreement with observations made under natural infection conditions. The incidence of stem girdling and leaf spot caused by $Q$. eucalypti usually occurs in clonal minihedges where wounds are artificially made when collecting minicuttings for rooting (Alfenas et al., 2004).

Spore germination did not differ between eucalypt clones UFV100 and UFV101 (data not shown). Xavier et al. (2001) observed similar results in the P. psidii and E. grandis pathosystem, finding no differences between susceptible and resistant genotypes for urediniospore germination, appressorium formation and host penetration, results similar to those reported by Liu \& Harder (1996) and by Ortelli et al. (1996).

Q. eucalypti was able to infect and produce more spores in young tissues located in the upper third of the plant. Ramularia shoot blight, caused by the fungus $Q$. pitereka (formerly Ramularia pitereka J. Walker \& Bertus 


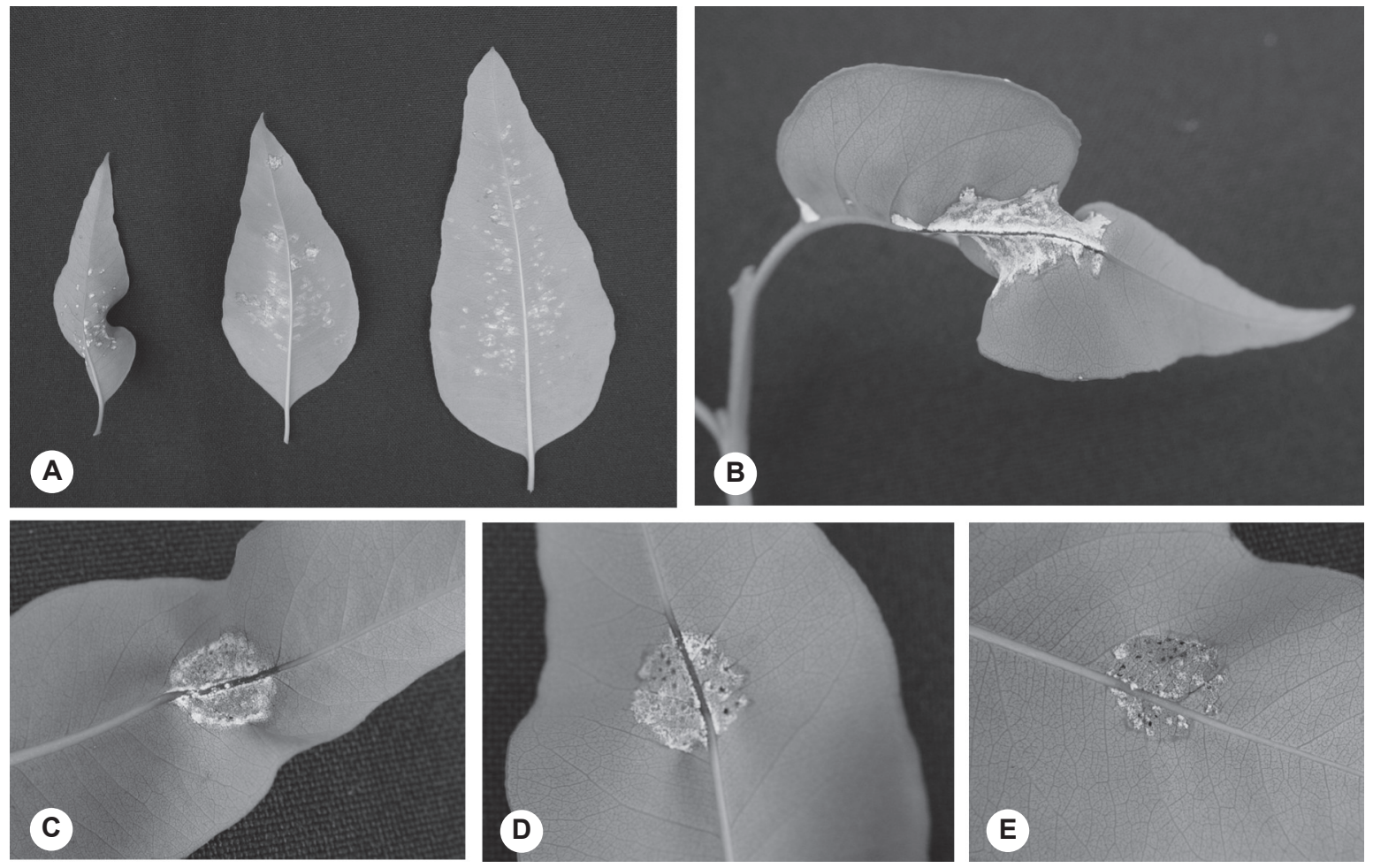

FIGURE 2 - Infection frequency and spore production as a function of leaf surface infected by Quambalaria eucalypti: A and B. Typical white fungal spore masses on abaxial leaf surface; C. Secondary spores produced in expanding ; D. expanded, E. old leaves.

and Sporothrix pitereka (J. Walker \& Bertus) U. Braun), typically affects the new shoots of young trees of spotted gums and some other Corymbia species. Spores of $Q$. pitereka germinate very rapidly on leaf surfaces, with at least $50 \%$ germination taking place in five hours. Tiny lesions subsequently develop on immature leaves and stems within five days. These may develop into large, sporulating lesions by day 10 . The disease cycle can, therefore, be completed within 10 days under favourable conditions (Ivory et al., 2002). Other pathogens are known that preferentially infect new leaves, such as the eucalypt rust $P$. psidii, which is affected by host phenology (Xavier et al., 2001) and other pathosystems (Eshenaur \& Milholland, 1989; Nita et al., 2003). On the other hand, there are pathogens that preferentially infect old leaves (Chang \& Hwang, 2003; Cox and Hosford, 1987; Hosford et al., 1990; Hosford et al., 1987; Jonsson et al., 1998; Raymond et al., 1985; Riaz et al., 1991; Tekauz, 1986). Chang \& Hwang (2003) observed that adlay plant leaf position and age had a significant influence on leaf blight severity, which was higher on the lower (older) leaves than on the upper (younger) leaves, regardless of growth stage and cultivar. Nita et al. (2003) observed the highest disease intensity in the youngest leaflets in the Phomopsis obscurans and strawberry pathosystem. The leaflets probably develop some type of ontogenic resistance with aging (Popular, 1978). Thus, it is important to evaluate the influence of plant tissue phenological age on pathogen infection, in order to provide information necessary for defining control strategies.

Penetration was more prevalent on the abaxial leaf surface. Blodgett \& Swart (2002) observed differences in colonization of leaf surfaces that they attributed to variation in stomatal frequency. However, in the $Q$. eucalypti disease, this was probably caused by the more favorable phyloplan environmental conditions for the onset of pathogen infection, survival and multiplication. Changes in amounts of wax between surfaces of leaves of varying ages may also affect pathogen behavior and consequently affect the infection process (Martin, 1964). In peanuts the resistance of old leaves to Puccinia arachidis Speg. is related to the increase in wax quantity on the leaf surface (Cook, 1980). Different leaf surface topographies, which affect wax arrangement and quantity, must also be considered. Although the mechanisms of pathogenesis of $Q$. eucalypti are currently unknown, physical and chemical changes may be related to the ability of the fungus to recognize and respond to surface stimuli.

Extensive leaf surface colonization was observed by SEM, even without evidence of infection. However, 
hyphal feeding tubes underneath the growth hyphae may have been present, which will only be proven through micromanipulation combined with transmission electron microscopy. Furthermore, the hyphae did not present preferential growth towards open stomata. Kilaru \& Hasenstein (2005) observed that the primary mycelium of Crinipellis perniciosa did not show any tropic response or preferential growth toward open stomata in cacao leaves.

High colonization capacity and spore production may favor $Q$. eucalypti establishment in the host tissue. In clonal mini-hedges there is a constant availability of new plant tissue, favoring infection by pathogens. The fact that the pathogen penetrates the host directly through wounded leaves and stems has implications for control strategies against this disease. Chemical and biological control agents must focus on the abaxial surface, where there are more favorable environmental conditions to penetration.

Old C. pteridis and P. psidii lesions did not serve as infection sites for the pathogen, as usually occurs with Pilidiella eucalyptorum (=Coniella fragariae) in eucalypt (Alfenas et al., 2004). It is thus believed that $Q$. eucalypti is not an efficient competitor or that it infects preferentially through recent wounds, such as those routinely found in mini-hedges, which could be related to the need for wound site exudates to permit pathogen establishment on the leaf surface.

In clonal mini-hedges young plant tissue, such as expanding leaves, is always present because of pruning, which increases pathogen infection. In this case, it is possible to optimize control approaches such as emergency application of chemicals after pruning. Our results showed that $Q$. eucalypti penetrated through wounds in young expanding leaves located in the upper third of eucalypti plants. This information will be useful in developing artificial inoculation procedures used for selection of resistant lineages, among other goals.

\section{REFERENCES}

Alfenas AC, Zauza EAV, Mafia RG, Assis TF (2004) Clonagem e Doenças do Eucalipto. Viçosa MG. Editora UFV.

Blodgett JT, Swart WJ (2002) Infection, colonization, and disease of Amaranthus hybridus leaves by the Alternaria tenuissima group. Plant Disease 86:1199-1205.

Chang SW, Hwang BK (2003) Effects of plant age, leaf position, inoculum density, and wetness period on Bipolaris coicis infection in adlays of differing resistance. Plant Disease 87:821-826.

Cook M (1980) Host-parasite relations in uredial infections of peanut by Puccinia arachidis. Phytopathology 70:822-826.
Cox DJ, Hosford RMJr (1987) Resistance winter wheats compared at differing growth stages and leaf positions for tan spot severity. Plant Disease 71:883-886.

Eshenaur BC, Milholland RD (1989) Factors influencing the growth of Phomopsis obscurans and disease development on strawberry leaf and runner tissue. Plant Disease 73: 814-819.

Hosford RMJr, Jordahl JG, Hammond JJ (1990) Effect of wheat genotype, leaf position, growth stage, fungal isolate, and wet period on tan spot lesions. Plant Disease 74:385-390.

Hosford RMJr, Larez CR, Hammond JJ (1987) Interaction of wet period and temperature on Pyrenophora tritici-repentis infection and development in wheats of differing resistance. Phytopathology 77:1021-1027.

Ivory M, Pegg GS, Brown B (2002) Shoot blight of spotted gums in Queensland. DPI Note FOR0049. Queensland Forestry Research Institute, Agency for Food and Fibre Sciences, DPI. Replaces QFRI Advisory Leaflet 24.

Jonsson R, Bryngelsson T, Jalli M, Gustafsson M (1998) Effect of growth stage on resistance to Drechslera teres f. teres in barley. Journal of Phytopathology 46:261-265.

Kilaru A, Hasenstein KH (2005) Development and pathogenicity of the fungus Crinipellis perniciosa on interaction with cacao leaves. Phytopathology 95:101-107.

Liu JQ, Harder DE (1996) Components of resistance in barley to stem rust: pre- and pos-penetration development in seedling and adult plant leaves. Canadian Journal of Botany 74:1305-1312.

Martin JT (1964) Role of cuticle in the defense against plant disease. Annual Review of Phytopathology 2:81-100.

Nita M, Ellis MA, Madden LV (2003) Effects of temperature, wetness duration, and leaflet age on infection of strawberry foliage by Phomopsis obscurans. Plant Disease 87:579-584.

Ortelli S, Gienzendanner U, Nosbergeer J (1996) Effect of the Lr9 resistance gene on pathogenesis of the wheat leaf rust fungus. Plant Disease 80:14-18.

Popular C (1978) Changes in host susceptibility with time. In: Horsfall JG, Cowling EB (Eds.) Plant Disease: An Advanced Treatise. Vol. II. New York NY. Academic Press. pp. 239-260.

Raymond PJ, Bockus WW, Norman BL (1985) Tan spot of winter wheat: Procedures to determine host response. Phytopathology 75:686-690.

Riaz M, Bockus WW, Davis MA(1991) Effects of wheat genotype, time after inoculation, and leaf age on conidia production by Drechslera tritici-repentis. Phytopathology 81:1298-1302.

Roux J, Mthalane ZL, de Beer ZW, Eisenberg B, Wingfield MJ (2006) Quambalaria leaf and shoot blight on Eucalyptus nitens in South Africa. Australasian Plant Pathology 35:427-433.

Simpson JA (2000) Quambalaria, a new genus of Eucalypt pathogens. Australian Mycologist 19:57-62.

Souza W (1998) Técnicas básicas de microscopia eletrônica aplicadas às ciências biológicas. Sociedade Brasileira de Microscopia, Rio de Janeiro RJ.

Tekauz A (1986) Effect of plant age and leaf position on the reaction of barley to Pyrenophora teres. Canadian Journal of Plant Pathology 8:380-386.

Wingfield MJ, Crous PW, Swart WJ (1993) Sporothrix eucalypti 
Effects of leaf position, surface, and entry sites on Quambalaria eucalypti...

(sp. nov.), a shoot and leaf pathogen of Eucalyptus in South Africa. Mycopathologia 123:159-164.

Xavier AA, Alfenas AC, Matsuoka K, Hodges CS (2001) Infection of resistant and susceptible Eucalyptus grandis genotypes by urediniosporos of Puccinia psidii. Australasian Plant Pathology 30:277-281.
Zauza EAV, Alfenas AC, Langrell SRH, Tommerup IC (2003) Detection and identification of Quambalaria species in Eucalyptus nurseries and plantations. Proceedings of the 8th International Congress of Plant Pathology, Christchurch, New Zealand. p. 113.

Received 26 September 2008 - Accepted 27 February 2009 - TPP 8115 Associate Editor: Nilceu R.X. Nazareno 